Article

\title{
Ports Opening for Seafarer Change during the COVID-19: Models and Applications
}

\author{
Yu Guo ${ }^{1}$, Ran Yan ${ }^{1, *}$, Yiwei $W^{1}{ }^{1}$ and Hans Wang ${ }^{2}$ \\ 1 Department of Logistics and Maritime Studies, The Hong Kong Polytechnic University, Hung Hom, \\ Kowloon, Hong Kong; christine-yu.guo@connect.polyu.hk (Y.G.); yiwei.wu@connect.polyu.hk (Y.W.) \\ 2 Faculty of Business, The Hong Kong Polytechnic University, Hung Hom, Kowloon, Hong Kong; \\ hans.wang@polyu.edu.hk \\ * Correspondence: angel-ran.yan@connect.polyu.hk
}

Citation: Guo, Y.; Yan, R.; Wu, Y.; Wang, H. Ports Opening for Seafarer Change during the COVID-19:

Models and Applications.

Sustainability 2022, 14, 2908.

https://doi.org/10.3390/su14052908

Academic Editor: Armando Cartenì

Received: 28 January 2022

Accepted: 28 February 2022

Published: 2 March 2022

Publisher's Note: MDPI stays neutral with regard to jurisdictional claims in published maps and institutional affiliations.

Copyright: (c) 2022 by the authors. Licensee MDPI, Basel, Switzerland. This article is an open access article distributed under the terms and conditions of the Creative Commons Attribution (CC BY) license (https:// creativecommons.org/licenses/by/ $4.0 /)$.

\begin{abstract}
Countries around the world have tightened their border controls in response to the spread of COVID-19. Consequently, seafarers are prohibited from boarding or leaving ships at most ports, with few exceptions. This situation means that seafarers are highly likely to serve onboard vessels beyond their contracted shifts. Most seafarers are prone to depression because they have to spend long periods at sea away from family and friends, and, thus, banning crew changes will put their mental health further at risk. This will increase the likelihood of maritime accidents, thus jeopardizing global supply chains and ultimately exacerbating current hardships. To tackle this emergency, the International Maritime Organization and the European Commission have called on governments to coordinate efforts to designate ports for crew changes during the pandemic. This study aims to solve the crew change problem by using an integer linear programming model. In the sensitivity analysis section, we find that the number of opening ports for crew changes and the cost of crew changes decrease when the cost of opening ports increases. The results show governments will not invest in opening more ports when the cost of opening ports increases. However, the penalty increases when the number of open ports decreases, and the cost of opening ports increases. As the number of crew changes is decreasing, this leads to the penalty increasing, when the number of open ports decreases.
\end{abstract}

Keywords: shipping; COVID-19; seafarer change; ILP model; penalty

\section{Introduction}

Shipping is the backbone of international trade [1]. The United Nations Conference on Trade and Development [2] estimated that the annual global volume of seaborne shipments in 2020 was 10.6 billion tons. To keep the global economy running, especially in difficult circumstances such as the COVID-19 pandemic, it is vital to keep ships sailing and goods, especially medical supplies and food, moving [3,4].

At sea, the global merchant fleet is operated by 1.65 million seafarers. Seafarers are required to sign long term contracts with shipping companies that specify the length of period spent onboard, which is usually weeks or months; thus, they stay at sea for long periods of time and endure separation from home and society [5]. Seafaring is a highly stressful profession [6], and seafarers are prone to both physical and mental exhaustion [7,8]. In addition, they experience many stressors, such as separation from family, loneliness, cross cultural miscommunication, fatigue and sleep deprivation, physical problems, lack of recreation, workplace noise, ship movement, vibration, and heat $[9,10]$.

Crew changes are, therefore, essential for the functioning of international shipping. Normally, every month, approximately 100,000 seafarers disembark from the ships that they operate to comply with regulations governing safe working hours and crew welfare, and are replaced by others [11]. Crew change keeps global trade moving smoothly. However, because countries have tightened their borders in response to the spread of COVID-19, seafarers are prohibited from boarding or leaving ships at most ports, and many remain 
on their vessels after their contracted shifts. Given that more than a quarter of seafarers suffer from depression, banning crew changes would further put their mental health at risk [12], increasing the likelihood of marine accidents, jeopardizing global supply chains, and ultimately exacerbating current hardships.

Some authorities have attempted to alleviate the obstacles of crew changes. For example, the U.K. and Jamaica have categorized seafarer change as an essential service [13,14]. In addition, Singapore have allowed seafarers whose contract has expired to change [15]. Ports in Canada have remained open for crew changes [16]. Moreover, the International Maritime Organization (IMO) and the European Commission have called on governments to coordinate efforts to designate ports for crew changes [17]. IMO and Doumbia-Henry [18] proposed that the safety of crew changes should be ensured [19].

Research in this area has focused on seafarers' physical and mental stress and the shortage of seafarers. These problems have become more severe during the COVID-19 pandemic. Crew members are exposed for months on end to high levels of physical and mental stress [8]. Strained family relationships and social isolation are considered the major antecedents of perceived stress [20]. Researchers from Cardiff University [21] surveyed 1856 seafarers and found that they experienced significant job related stress and suffered as a result of excessive working hours (often more than $12 \mathrm{~h}$ a day), a situation hidden by an alarming number of falsified records. Over $40 \%$ of seafarers reported disturbed sleep, mainly due to noise and motion.

Seafarers' job related stress is a major cause of maritime accidents [22] and burnout [23]. An Australian team summarized the maritime accident data from 1960 to 2009 and reported that more than 9000 seafarers had committed suicide or disappeared at sea during this period. This suggests that seafarers have poor mental health, which can have fatal consequences [24]. This result was echoed by a study conducted by a team at Yale University in 2019 , which showed that $20 \%$ of seafarers had either considered or attempted suicide [21]. Due to chronic physical and mental fatigue, overworking, and isolation from family and friends, seafarers may decide to leave their jobs, and the industry has found it difficult to attract enough new employees to make up the shortfall. The International Chamber of Shipping forecasted the global supply of, and demand for, seafarers, which foresaw a future shortage of seafarers [25].

The IMO reported that, during the COVID-19 pandemic, more than 100,000 seafarers stayed at sea for months beyond the end of their contracts [26]. This situation has caused great mental stress, fatigue, and exhaustion to seafarers, increasing the risks associated with sailing. Crew change is an important part of ensuring the physical and mental health of the seafarers. Due to the difficulties in changing crew during the epidemic, their psychological condition worsened. Therefore, we propose to use an integer linear programming (ILP) model to solve the problem of opening ports to help crew change, which is beneficial to their physical and mental health. An ILP model means that the variables in the plan (all or part) are restricted to integers. If, in a linear model, the variables are restricted to integers, it is called integer linear programming.

\section{Problem Description}

Opening ports will induce different kinds of costs, such as port management costs and quarantine costs, amongst others. Hence, we mainly consider the costs of a port opening for crew change as the key factor. A mathematical model to minimize the total cost of opening ports and crew change penalties is presented in this section. A penalty means that the shipowner needs to pay extra costs to the seafarer, per day, if the current total working days of the seafarer extend past the contract (10 months). The measure of a penalty can prevent seafarers from continuing to work out of the contract and benefit crew change. A set of ports, $P$, indexed by $p \in\{1,2, \ldots,|P|\}$, is available to serve a set of ships, $S$, indexed by $s \in\{1,2, \ldots,|S|\}$. The ports are assumed to be discrete and able to handle the ships' docking. Assume that each ship docks at a port once and $t_{s p}$ is the arrival time of ship $s$ to port $p$. Here, $\Delta_{s p}$ is set to 1 if ship $s$ docks at port $p$ during a planning 
horizon, and 0 otherwise. The total number of crew members on ship $s$ is denoted as $M_{s}$. We use $m \in\left\{1,2, \ldots, M_{s}\right\}$ to index the crew members on ship $s$. The number of days that crew member $m$ has worked is $\tau_{m s}$. We assume that the period of a crew member's contract, e.g., 10 months, is $\gamma$, and that a new crew member will not disembark during a planning horizon.

The objective function of this problem includes the cost of one change in seafarers $(\alpha)$, the penalty $(d)$ per day for a crew working beyond the contracted period, and the cost $(C)$ for opening a port. Hence, we need to find the minimum sum of the total costs of opening a port/ports and crew changes, and the penalties.

\section{An ILP Model}

We address the problem of minimizing the crew change cost and penalty described in Section 2 by developing an ILP model. The following assumptions are made as part of the proposed formulations.

(1) There is no interruption during crew change activities;

(2) The ports that allow crew change can be opened immediately by the government when the total social cost is minimized;

(3) The duration of the contracts of all crew members is identical (e.g., 10 months);

(4) During the planning horizon, each ship docks at the port once and is allowed to change one crew;

(5) The cost of opening a port for crew change is identical for all regions. The cost of a crew change is also the same for all ships. In addition, the penalty for each crew is the same.

The notation used in this study is defined as follows.

Indices, sets, and parameters.

$P$ set of ports, $p \in\{1,2, \ldots,|P|\}$;

$S$ set of ships, $s \in\{1,2, \ldots,|S|\}$;

$\gamma$ duration of a crew's contract;

$M_{S}$ number of all crew members;

$\tau_{m s}$ number of days that crew $m$ has worked on ship $s$;

$t_{s p}$ arrival time of ship $s$ at port $p$;

$T$ duration of a planning horizon, e.g., 365 days;

$\alpha$ cost of changing a crew;

$d$ penalty per day for each crew working beyond the contract;

$C$ cost of opening a port;

$\Delta_{s p}$ parameter that equals 1 if ship $s$ docks at port $p$ during a planning horizon, and 0 otherwise.

Decision variables.

The $x_{p}$ decision variable is set to 1 if port $p$ is open to allow seafarer changes at the beginning of the planning horizon; otherwise, it is set to 0 ;

The $y_{\text {spm }}$ decision variable is set to 1 if crew member $m$ is changed when ship $s$ docks at port $p$; otherwise, it is set to 0 .

Furthermore, we denote $C_{T}$ as the total cost based on the above definitions of the parameters and decision variables. Finally, the ILP model is formulated as follows:

$\operatorname{Min} C_{T}=\sum_{p \in P} \quad C x_{p}$

$$
\begin{aligned}
& +\sum_{s \in \mathrm{S}} \sum_{m=1}^{M_{s}}\left\{\sum_{p \in P} y_{s p m}\left[\alpha+d \max \left(t_{s p}+\tau_{m s}-\gamma, 0\right)+d \max \left(T-t_{s p}-\gamma, 0\right)\right]\right. \\
& \left.+\left(1-\sum_{p \in P} y_{s p m}\right) d \max \left(\tau_{m s}+T-\gamma, 0\right)\right\}
\end{aligned}
$$

subject to

$$
\begin{gathered}
\sum_{p \in P} x_{p} \geq 1 \\
y_{s p m} \leq x_{p} \forall s \in S, \forall p \in P, \forall m \in\left\{1,2, \ldots, M_{s}\right\}
\end{gathered}
$$




$$
\begin{gathered}
y_{s p m} \leq \Delta_{s p} \forall s \in S, \forall p \in P, \forall m \in\left\{1,2, \ldots, M_{s}\right\} \\
\sum_{p \in P} y_{s p m} \leq 1 \forall s \in S, \forall m \in\left\{1,2, \ldots, M_{s}\right\} \\
x_{p} \in\{0,1\} \forall p \in P \\
y_{s p m} \in\{0,1\} \forall s \in S, \forall p \in P, \forall m \in\left\{1,2, \ldots, M_{s}\right\} .
\end{gathered}
$$

Objective Function (1) minimizes the sum of the costs of opening ports and crew change and the penalty of staying beyond the contract. Specifically, the term $\alpha+d \max \left(t_{s p}+\tau_{m s}-\gamma, 0\right)+d \max \left(T-t_{s p}-\gamma, 0\right)$ is the crew change related cost if crew $m$ on ship $s$ is changed at port $p$. In addition, $\alpha$ is the cost of a crew change, $d \max \left(t_{s p}+\tau_{m s}-\gamma, 0\right)$ is the penalty for an existing crew member working beyond the contract, and $d \max \left(T-t_{s p}-\gamma, 0\right)$ is the penalty for a new crew member working beyond the contract. Moreover, term $d \max \left(\tau_{m s}+T-\gamma, 0\right)$ is the crew change related cost if crew $m$ on ship $s$ is not changed during the planning horizon, which is the penalty for an existing crew member working beyond the contract. Constraint (2) ensures that at least one port is open for crew change. Constraint (4) ensures that a crew can be changed when ship $s$ docks in port $p$. Constraint (5) states that at most one crew member can disembark from ship $s$ in a port. Finally, constraints (6) and (7) guarantee the domain of the decision variables.

\section{Numerical Experiments}

To evaluate the proposed model, we perform several computational experiments using a PC (Intel Core i7; memory, 16 GB, Mountain View, CA, USA). The mathematical model proposed in this study is coded in $C^{\#}$ and implemented by CPLEX 12.6.2. CPLEX is a mathematical optimization technique, which is used to increase efficiency, implement strategies quickly, and increase profitability.

\subsection{Performance of the Model}

We first summarize our parameter settings. The planning horizon is 365 days. The contract of each crew member is 300 days. As mentioned above, the cost in the objective function includes three parts: opening ports, crew change, and the penalty. The cost of the crew change for each crew member is USD 4000, which is in line with maritime news [27]. There is a penalty if the crew member's working days extend beyond the contract, and this penalty is assumed to be USD 100 for one crew member per day. Data on working days for each crew member, routes for each ship, and the dock time for each ship are randomly generated.

Several numerical experiments considering scenarios with different numbers of ship routes are carried out to validate the proposed model. Table 1 lists the results provided directly by CPLEX. The number of ports include total ports, and the number of routes represents different schemes of docking ports, which means that ships docks at different ports among the total ports. We consider the same number of ports on different routes in a single instance. CPU time represents the running time for each instance in seconds. We find that the CPU running time increases in different instances with the same number of ports: as the number of routes increases, so does the CPU running time. 
Table 1. Results provided by CPLEX.

\begin{tabular}{cccc}
\hline Instance No. & Number of Ports & Number of Routes & CPU Time (s) \\
\hline 1 & 5 & 5 & 143 \\
2 & 5 & 10 & 186 \\
3 & 5 & 15 & 202 \\
4 & 5 & 20 & 218 \\
5 & 10 & 5 & 189 \\
6 & 10 & 10 & 226 \\
7 & 10 & 15 & 278 \\
8 & 10 & 20 & 312 \\
9 & 15 & 5 & 214 \\
10 & 15 & 10 & 264 \\
11 & 15 & 15 & 316 \\
12 & 15 & 20 & 350 \\
\hline
\end{tabular}

\subsection{Sensitive Analysis}

In this section, we discuss how the cost of opening ports can influence the number of open ports, the number of crew changes, the penalty, the cost of crew changes, and the total cost. To achieve this goal, we use Instance 1 with five total ports and five different routes to conduct a sensitivity analysis. In this instance, the parameters (the number of total ships, the days worked, the total number of crew members, the penalty for each crew member working beyond the contract's end, and the cost for each crew change) are identical. We want to find the influence on total cost, the number of open ports, the penalty, and the number of crew changes by changing the cost of opening a port.

We first discuss the relationship between the cost of opening a port and the number of open ports by increasing the cost of opening ports. The results presented in Figure 1 indicate that cost of opening ports and the number of open ports is negatively correlated. We find that the number of open ports that permit a crew change decreases from three to one when the cost of opening port increases to USD 500,000 (but not to zero because we require that at least one port be open for crew change). Only one port opens for crew change when the cost increases from USD 500,000 to USD 600,000.

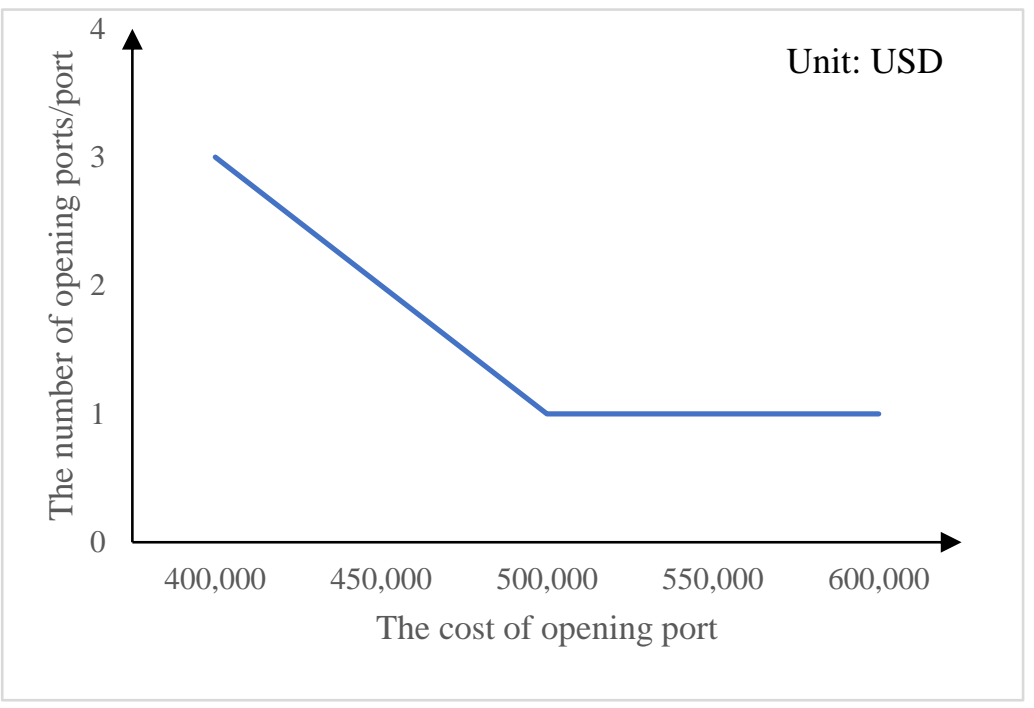

Figure 1. The number of open ports as the cost of opening port increases.

Next, we discuss the relationship between the cost of opening ports and the crew change penalty. The results presented in Figure 2 indicate that the penalty increases when fewer ports are open for crew changes. Furthermore, it indicates that crew change priority 
is given to crews whose days worked go beyond the contract. Hence, the penalty is smaller when three ports are open for crew changes.

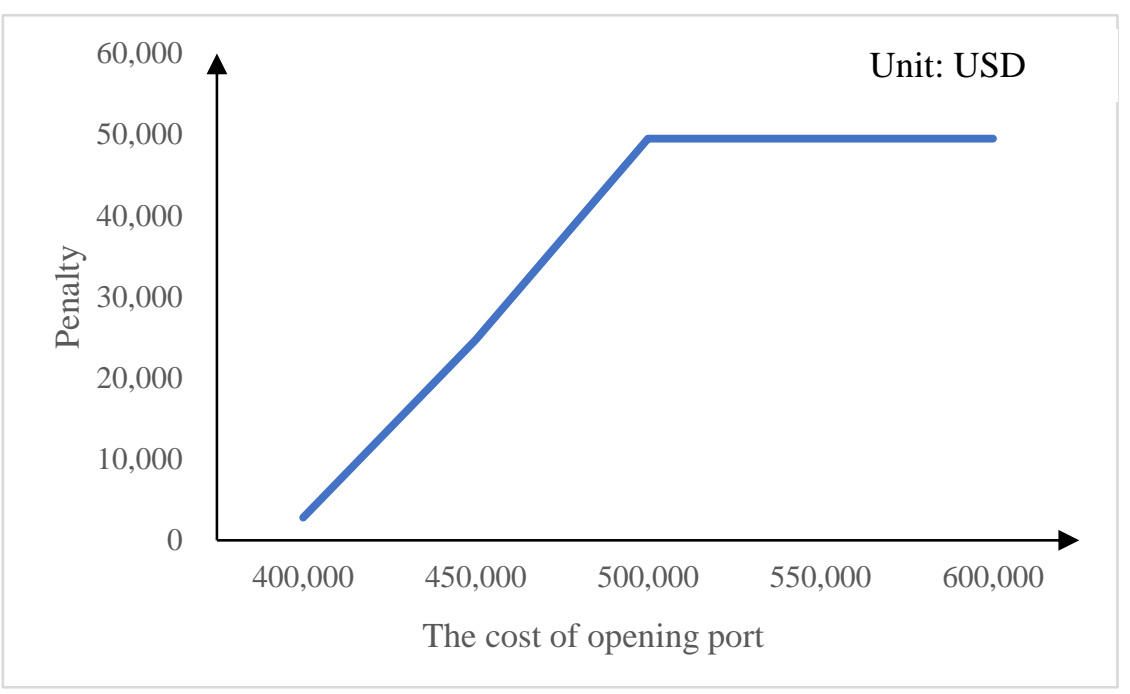

Figure 2. The penalty as the cost of opening port increases.

Next, we want to find the relationship between the cost of opening ports and the cost of crew changes. It can be seen from Figure 3 that the cost of crew changes decreases as the cost of opening a port increases. From the results in Figure 2, we can conclude that fewer crews can be changed when fewer ports are open for crew changes.

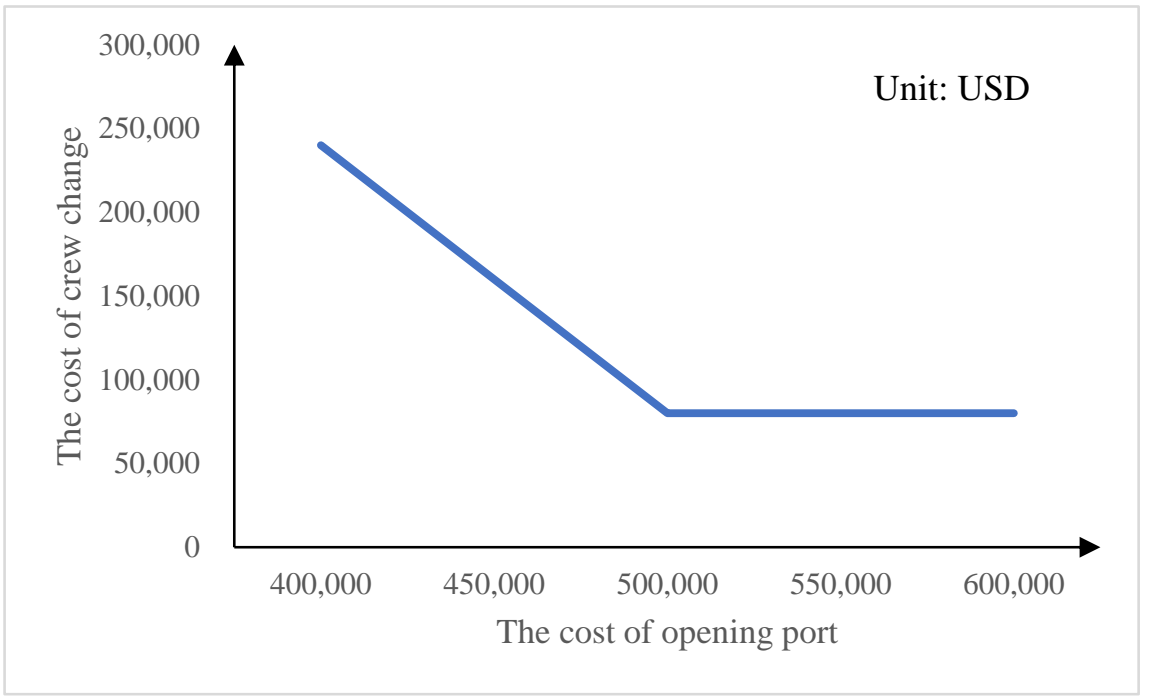

Figure 3. The cost of crew changes as the cost of opening port increases.

Finally, we want to find how the total cost reflects increases in the cost of opening a port. As the results plotted in Table 2 show, the total cost increases from USD 627,400 to USD 917,200 as the cost of opening a port increases from USD 400,000 to USD 500,000. It is also interesting to find that the total cost increases slowly after USD 500,000. This is because, as discussed above, we require that at least one port to be open for crew change, and the cost increases from USD 500,000 to USD 600,000. As the penalty cost and the cost of crew change remain unchanged when the cost of opening a port increases from USD 500,000 to USD 600,000, the total cost increases more slowly after USD 500,000. 
Table 2. The total cost as the cost of opening a port increases.

\begin{tabular}{ccc}
\hline Case No. & The Cost of Opening a Port & The Total Cost \\
\hline 1 & USD 400,000 & USD 627,400 \\
2 & USD 450,000 & USD 777,000 \\
3 & USD 500,000 & USD 917,200 \\
4 & USD 550,000 967,200 \\
5 & USD 600,000 & USD 1,017,200 \\
\hline
\end{tabular}

\subsection{Discussion}

In this section, we use an instance that is calculated by CPLEX to find how the cost of opening ports can influence the number of open ports, the number of crew changes, the penalty, the cost of crew changes, and the total cost. However, there are some limitations.

First, the instance might not be sufficient to conclude all cases in normal shipping activities because we need to consider more parameters in reality, e.g., ship delay costs. Thus, in future research, more parameters should be considered in this model. Second, the scale of crew changes and ports opening might be larger than the model proposed for shipping activities during the normal period. However, due to the lack of the real data, the data used in numerical experiments are assumed within a certain range, including the current working days of crew members, the penalty and the routes of the ships. The results of the model can provide some suggestions based on the assumed data. Hence, it can be expected that we would obtain more reliable conclusions after gaining the real data in the future research.

\section{Conclusions}

Shipping is the most cost effective way to transport large volumes of goods over long distances. To keep the global economy running, it is vital to keep ships sailing during the COVID-19 pandemic. Every month, around 100,000 seafarers need to disembark from the ships that they operate to comply with regulations governing safe working hours and crew welfare, and then another 100,000 seafarers embark. However, seafarers are prohibited from boarding or leaving ships at most ports because of COVID-19 restrictions, which increases seafarers' stress and fatigue. This problem cannot be fully addressed unless autonomous ships are prevalent in the world [28-30].

This study aims to solve the problem of seafarers' crew change. We propose an ILP model by considering three components: opening ports, crew change, and penalty. We propose 12 instances for the ILP model solved by CPLEX, which demonstrates the computational efficiency of our model.

Lastly, we conduct a sensitivity analysis by choosing one instance to discuss how the cost of opening a port can influence the number of open ports, the number of crew changes, the penalty, the cost of crew changes, and the total cost. We find that the number of ports open for crew changes and the cost of crew changes decrease when the cost of opening ports increases. The penalty and total cost increase when the cost of opening ports increases. It can thus be concluded that, when the cost of opening a port is high, the risks associated with crew change will increase because fewer ports will be open for crew changes.

We believe the study has positive impacts on two aspects: seafarers and society. Seafarers are vulnerable to epidemics. It is difficult for them to receive immediate medical treatment once they contract an epidemic at sea. Most seafarers must disembark at foreign ports. However, during the epidemic, many countries close their borders. Thus, seafarers must stay at sea far beyond the contract period and do not know when they can return home. Considering that, under normal circumstances, seafarers have to work in an isolated environment for months and suffer from stress, anxiety and depression, banning them from disembarking will be detrimental to their mental health. This study can solve the problem of mental health and is beneficial to seafarers.

For society, crew changes will enable them to maintain world trade and strengthen the global response to epidemics. Shipping is the most cost effective way to transport large 
quantities of goods over long distances. More than $80 \%$ of global trade is transported by sea, including food, medical supplies, energy, raw materials and finished products. Some production activities are stopped during epidemics to prevent the spread of diseases. Then, shipping plays a more important role in maintaining global supply chains and providing basic food and medical supplies to many countries. Therefore, facilitating crew change can ensure normal shipping activities.

Author Contributions: Conceptualization, H.W., Y.G., Y.W. and R.Y.; methodology, H.W., Y.G., Y.W. and R.Y.; software, Y.G. and Y.W.; validation, Y.G., R.Y., Y.W. and H.W.; formal analysis, Y.G., R.Y., Y.W. and H.W.; investigation, Y.G., R.Y., Y.W. and H.W.; resources, Y.G.; data curation, Y.G.; writingoriginal draft preparation, Y.G.; writing — review and editing, Y.G., R.Y., Y.W. and H.W.; visualization, Y.G.; supervision, R.Y., Y.W. and H.W.; project administration, H.W. All authors have read and agreed to the published version of the manuscript.

Funding: Not applicable.

Institutional Review Board Statement: Not applicable.

Informed Consent Statement: Not applicable.

Data Availability Statement: Not applicable.

Conflicts of Interest: The authors declare no conflict of interest.

\section{References}

1. Wang, S.; Psaraftis, H.N.; Qi, J. Paradox of international maritime organization's carbon intensity indicator. Commun. Transp. Res. 2021, 1, 100005. [CrossRef]

2. United Nations Conference on Trade and Development (UNCTD). 11 June 2021. Available online: https:/ / hbs.unctad.org/worldseaborne-trade/ (accessed on 15 February 2022).

3. Qi, J.; Wang, S.; Psaraftis, H. Bi-level optimization model applications in managing air emissions from ships: A review. Commun. Transp. Res. 2021, 1, 100020. [CrossRef]

4. Yan, R.; Wang, S.; Zhen, L.; Laporte, G. Emerging approaches applied to maritime transport research: Past and future. Commun. Transp. Res. 2021, 1, 100011. [CrossRef]

5. Carotenuto, A.; Molino, I.; Fasanaro, A. Psychological stress in seafarers: A review. Int. Marit. Health 2012, 63, 188-194. [PubMed]

6. Oldenburg, M.; Baur, X.; Schlaich, C. Occupational risks and challenges of seafaring. J. Occup. Health 2010, 52, 249. [CrossRef] [PubMed]

7. Hystad, S.; Eid, J. Sleep and fatigue among seafarers: The role of environmental stressors, duration at sea and psychological capital. Saf. Health Work 2016, 7, 363-371. [CrossRef] [PubMed]

8. Oldenburg, M.; Jensen, H.J. Merchant seafaring: A changing and hazardous occupation. Occup. Environ. Med. 2012, 69, 685-688. [CrossRef] [PubMed]

9. Jepsen, J.; Zhao, Z.; Leeuwen, W. Seafarer fatigue: A review of risk factors, consequences for seafarers' health and safety and options for mitigation. Int. Marit. Health 2015, 66, 106-117. [CrossRef] [PubMed]

10. Oldenburg, M.; Hogan, B.; Jensen, H.J. Systematic review of maritime field studies about stress and strain in seafaring. Int. Arch. Occup. Environ. Health 2013, 86, 1-15. [CrossRef]

11. The Conversation. 4 May 2020. Available online: https://theconversation.com/thousands-of-seafarers-are-stranded-aboardships-with-no-end-to-their-shift-in-sight-137324 (accessed on 11 January 2022).

12. De Beukelaer, C. COVID-19 border closures cause humanitarian crew change crisis at sea. Mar. Policy 2021, 132, 104661-104665. [CrossRef]

13. Itfseafarers. 12 September 2020. Available online: https://www.itfseafarers.org/en/news/companies-must-take-crewchangeopportunities-uk-and-elsewhere-itf (accessed on 19 January 2022).

14. The Maritime Executive. 7 August 2020. Available online: https://maritimejamaica.com/News-Events/jamaica-opens-for-crewchanges-and-repatriations (accessed on 19 January 2022).

15. Seatrade. 25 May 2020. Available online: https://www.seatrade-maritime.com/regulation/singapore-allow-crew-changeswhere-seafarer-contracts-have-expired (accessed on 15 February 2022).

16. Seaman. 27 July 2020. Available online: https://54seaman.com/news/detail_136550.html (accessed on 27 July 2021).

17. BIMCO. 21 April 2021. Available online: https://www.bimco.org/news-and-trends/market-analysis (accessed on 15 February 2022).

18. Doumbia-Henry, C. Shipping and COVID-19: Protecting seafarers as frontline workers. WMU J. Marit. Aff. 2020, 19, 279-293. [CrossRef] 
19. IMO. Circular Letter Coronavirus (COVID-19)—Recommended Framework of Protocols for Ensuring Safe Ship Crew Changes and Travel during the Coronavirus (COVID-19) Pandemic. 2020. Available online: https://www.seafarerswelfare.org/seafarerhealth-information-programme/ coronavirus-covid-19/ coronavirus-covid-19-recommended-framework-of-protocols-forensuring-safe-ship-crew-changes-and-travel-during-the-coronavirus-covid-19-pandemic-2-december-2020 (accessed on 10 January 2022).

20. Iversen, R. The mental health of seafarers. Int. Marit. Health 2012, 63, 78-89.

21. Lefkowitz, R.Y.; Slade, M.D. Seafarer Mental Health Study. 2019. Available online: https://www.seafarerstrust.org/sites/default/ files/node/publications/files/ST_MentalHealthReport_Final_Digital-1.pdf (accessed on 1 July 2021).

22. Kim, J.; Jang, S. The relationship between job stress, job satisfaction, and the symptom checklist-90-revision (SCL-90-R) in marine officers on board. J. Prev. Med. Public Health 2016, 49, 376-385. [CrossRef]

23. Chung, Y.; Lee, P.; Lee, J. Burnout in seafarers: Its antecedents and effects on incidents at sea. Marit. Policy Manag. 2017, 44, 916-931. [CrossRef]

24. Smith, A.P.; Allen, P.H.; Wadsworth, E.J.K. Seafarer Fatigue. 2006. Available online: https://orca.cardiff.ac.uk/48167/1/research_ report_464.pdf (accessed on 2 July 2021).

25. International Labour Organization. 1 March 2019. Available online: https://www.ilo.org/wcmsp5/groups/public/---ed_ dialogue/sector/documents/document/wcms_712749.pdf (accessed on 11 February 2022).

26. Sohu. 1 January 2021. Available online: https://www.sohu.com/a/446396202_683946 (accessed on 22 July 2021).

27. Maritime. 12 November 2020. Available online: https://www.maritime-executive.com/article/cost-of-crew-change-skyrocketsdue-to-pandemic (accessed on 1 December 2021).

28. Peng, T.; Liu, X.; Fang, R.; Zhang, R.; Pang, Y.; Wang, T.; Tong, Y. Lane-change path planning and control method for self-driving articulated trucks. J. Intell. Connect. Veh. 2020, 3, 49-66. [CrossRef]

29. Mao, S.; Xiao, G.; Lee, J.; Wang, L.; Wang, Z.; Huang, H. Safety effects of work zone advisory systems under the intelligent connected vehicle environment: A microsimulation approach. J. Intell. Connect. Veh. 2021, 4, 16-27. [CrossRef]

30. Zhang, Z.; Yang, X.T. Analysis of highway performance under mixed connected and regular vehicle environment. J. Intell. Connect. Veh. 2021, 4, 68-79. [CrossRef] 